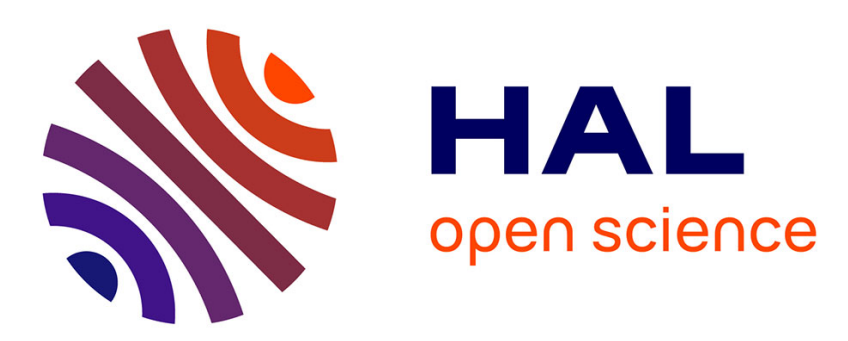

\title{
Training decision-makers: Existing strategies for natural and technological crisis management and specifications of an improved simulation-based tool
}

\author{
Florian Tena-Chollet, Jérôme Tixier, Aurélia Dandrieux, Pierre Slangen
}

\section{- To cite this version:}

Florian Tena-Chollet, Jérôme Tixier, Aurélia Dandrieux, Pierre Slangen. Training decision-makers: Existing strategies for natural and technological crisis management and specifications of an improved simulation-based tool. Safety Science, 2016, 97, pp.144-153. 10.1016/j.ssci.2016.03.025 . hal01534398

\author{
HAL Id: hal-01534398 \\ https://hal.science/hal-01534398
}

Submitted on 29 May 2018

HAL is a multi-disciplinary open access archive for the deposit and dissemination of scientific research documents, whether they are published or not. The documents may come from teaching and research institutions in France or abroad, or from public or private research centers.
L'archive ouverte pluridisciplinaire HAL, est destinée au dépôt et à la diffusion de documents scientifiques de niveau recherche, publiés ou non, émanant des établissements d'enseignement et de recherche français ou étrangers, des laboratoires publics ou privés. 


\title{
Training decision-makers: existing strategies for natural and technological crisis management and specifications of an improved simulation-based tool.
}

\author{
F. Tena-Chollet, J. Tixier, A. Dandrieux, P. Slangen \\ Ecole des Mines d'Alès, LGEI, 6 Avenue de Clavières, 30319 Alès Cedex, France
}

\begin{abstract}
Serious games and environmental computer-based simulations can be useful training tools for people who have to act in emergencies. Currently, stakeholders who deal with crises have to make decisions under stress, for example in order to mitigate consequences or avoid negative impacts on high-stake elements.

Many factors are critical in a training environment for ensuring that effective learning occurs, principally: experience improvement, engagement and immersion, and realism.

This paper aims to identify the limits of existing learning systems for emergency stakeholders within a crisis cell and then to propose a set of recommendations in order to specify a system to improve the effectiveness of peoples' actions in case of a major crisis.

The development of this approach requires the pooling of information concerning varied and multidisciplinary skills. The paper first focuses on the classical difficulties of crisis management, after which the notion of experience in decision-making is defined. The issue is studied from three points of view: the educational approach, the simulation system, and the training environment. The last section of this paper contributes to establishing a set of enhancements which can lead to the specification of simulation based learning systems for further development. More particularly, we specify the needed characteristics of our learning approach and teaching strategy. Finally, we propose a model with the main steps that have to be implemented in order to design a new learning system: a semi-virtual training environment for strategic crisis management.
\end{abstract}

KEYWORDS: major risk, learning environment, training, crisis management, decision-making, serious game. 


\section{INTRODUCTION}

Disasters impinging on the world over the last thirty years illustrate how most societies are increasingly faced with highly disruptive events (e.g. Fukushima in 2011).

According to Morin, the concept of emergency has spread to all areas but remains the sudden and intense appearance of a rupture event, which usually requires a human response [Morin et al., 2004]. In most countries, the emergency response is not only structured depending on the type of event and its intensity but also codified via a specific organizational system: the crisis cell [Wybo and Madland Kowalski, 1998; Dautun, 2007].

In the field of major risks, a crisis is characterized by a loss of control and thus a high level of stress for the stakeholders involved due to a "spark event" (i.e. an unexpected trigger) causing a disruption of the balance of a system (for example an organization, an infrastructure, a territory, etc.) [Marguin, 2002].

Crisis management involves quick decision-making in critical conditions, with the obligation of issuing a public report to the media [Sniezek et al., 2001; Lagadec, 2007]. Crises therefore lead decision-makers into an urgent decision-making situation, with the obligation to minimize the potential consequences for a wide range of high-stake elements [Tena-Chollet et al., 2013].

On the one hand, estimating the consequences of a decision taken in a risky situation is delicate due to the complexity of the available information and also because of the emergency context in which such strategic decisions must be taken. On the other hand, the decision-makers involved may become particularly vulnerable and hence unable to fulfill their missions with regard to events concerning the management of crises [Lachtar and Garbolino, 2012].

Recent works demonstrate that simulation games are effective tools in the teaching of management techniques and engineering and have been widely used in experiential learning [Mawdesley et al., 2011].

This subject is a research project studying the way to improve the conditions of cooperative learning of the actors involved in crises (stakeholders for example) within a closed group (a crisis cell). We believe the innovation of our approach is that we recognized the lack of suitable simulation-based training environments through a state-of-the-art study of existing educational strategies, and also that we identified key concepts and specifications that can guide the development of an innovative deployable learning system. 
The development of this approach requires the state of the art study concerning varied and multidisciplinary skills. The paper first focuses on the classical difficulties of crisis management, after which the notion of experience in decision-making is defined. The issue is studied from three points of view: the educational approach, the simulation system, and the training environment. Finally, the last section of this paper contributes to establishing a set of enhancements which can lead to the specification of simulation based learning systems for further development.

\section{CLASSICAL CRISIS MANAGEMENT DIFFICULTIES}

Many authors have noticed that the human factor, rather than existing plans, the management of resources, or the uncertainty of the situation, is often a major source of vulnerability in the decision-making process [Turner, 1978; Denis, 1993; Parkin, 1996; Pearson et al., 1997; Loosemore, 1998; Smith and Dowell, 2000; Weisæth et al., 2002; Sayegh et al., 2004; Crocq et al., 2009; Heiderich, 2010]. Conversely, decision-making, communication, mental model sharing, leadership and coordination are critical skills to be used by a crisis cell [Salas and CannonBowers, 1997; Dautun, 2007].

A rapid survey of past major accidents shows that management difficulties in emergency situations, problems of shared mental representations of an unknown problem, and behavior failures within a closed group, are the main sources of social vulnerability in decision-making groups [Tena-Chollet, 2012].

As a result, habits and knowledge which help to monitor the situation, to anticipate possible consequences, to choose concerted actions, and to communicate together and cooperate need to be taken into account. We thus propose to study all these skills, necessary for emergency management, through the decision-makers' experience.

\section{PARADOX OF EXPERIENCE IN EMERGENCY MANAGEMENT}

Theoretically, the processes of decision-making can be creative, analytical, procedural or naturalistic [Bryant et al., 2003]. In practice, a crisis involves critical stakes, significant effects and limited reaction times, and the decision-making process is thus mainly naturalistic [Shanteau, 1987; Means et al., 1993; Klein, 1997]. This raises the following paradox: although a crisis is exceptional, decisions during its management depend on previous experienced situations.

In order to achieve a common goal, each member of a crisis cell must perform tasks involving teamwork [Smith and Dowell, 2000; Schaafstal et al., 2001]. The study of characteristic profiles 
enables developers, evaluators and decision-makers to be distinguished. These three profiles mobilize the following non-specific technical skills: anticipation, communication, teamwork, stress management, decision-making, and leadership [Rasmussen, 1983; Weisæth, et al., 2002; Endsley, 2003; Crichton, 2009].

The uncertainty, complexity and fragmentation of the available information have a direct impact on the activation of the six skills mentioned above. Not only can decisions not be taken in full knowledge, but also require the cooperation of emergency management actors who are not always accustomed working together [Smith and Dowell, 2000]. These difficulties can lead to a lack of:

- Internal and external communications of the crisis cell [Lagadec, 1995];

- Shared mental models between actors [Cannon-Bowers et al., 1993].

It has been found that individualism can sometimes outweigh cooperation, and that the actions of members of the same social group (a crisis cell for example) can be degraded by the following human behaviors: alterability, subjectivity, ignorance, credulity, disaffection or asociality. However, these undesirable behaviors tend to disappear whenever a situation threatens to affect psychosocial factors. Human behaviors are for instance positively impacted by stress, and the following qualities can be observed: instinct, learning, intelligence and adaptability [Bates et al., 1991; Buser, 2002].

Several authors postulate that decision-making in a crisis requires previous learning, and training exercises are therefore a classic way to help crisis management stakeholders to implement strategies with hindsight [Lagadec, 2001; Dautun, 2007]. It is therefore necessary to study the different types of training provided in the crisis management field. The aim of this state-of-the-art is to check whether the required stakeholder skills are integrated in the existing training sessions, and in particular whether the simulated crises are realistic.

\section{RESEARCH ISSUES REGARDING THE TRAINING OF DECISION-MAKERS}

Training in crisis management aims to facilitate the transposition of learned skills from theory to practice (i.e. in real situations). During group sessions, learners can share their experiences, knowledge and points of view in order to experience new ways of thinking [Galvão et al., 2000].

\subsection{Training research}

The training session requires the following steps: planning, preparation, exercise, and reflexive analysis [Morin et al., 2004]. 
Usually, a training session can be based on exchanging roles, managing events, or acting under degraded conditions. This last type is also called "critical thinking training" (CTT) [Blickensderfer et al., 1998; Cohen et al., 1998; Fowlkes et al., 1998]. We can notice that the event-based approach to training (EBAT) uses naturalistic decision making [Fowlkes et al., 1998] and is thus directly in the scope of our research question. It is also interesting to note that the CTT approach covers some key concepts of crisis management, for example to cope with large amounts of information. Fig. 1 summarizes the main pros and cons of each training approach. We can see that the first one (based on the exchange of roles) is not adapted to our research (do not train on skills usually assumed by stakeholders).

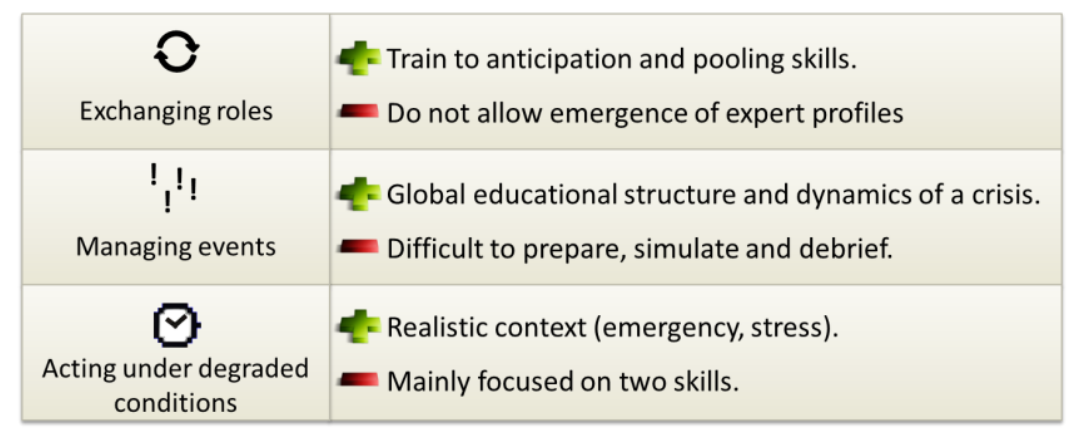

Fig. 1: pros and cons of the three main training approaches

Different types of exercises can be implemented: tabletop, real-life, or functional. Real-life exercises usually focus on specific tasks and mobilize many actors (stakeholders, emergency services, residents...). They are then difficult to organize and are often one shot exercises. Tabletop exercises help to test the capability of an organization to respond to a simulated event in terms of planning, preparation, and coordination, in a stress-free environment: equipment is not used, resources are not deployed, and time pressures are not introduced. Generally, tabletop exercises are focusing on specific parts of a crisis only. Functional exercises confer the advantage of working on the roles and interactions of everyone involved in the crisis and they are based on a simulated scenario, easily reproducible without having to mobilize all the stakeholders usually involved [Trnka and Jenvald, 2006]. Unlike tabletop exercises, they are also more faithful to the dynamics of crises. They thus facilitate the management of events and their evolution in fast time, real time or slow time simulation, and reduce their development costs [Laffitte and Howe, 1997]. Fig. 2 summarizes the main pros and cons of each type of exercise through the two approaches previously retained. 


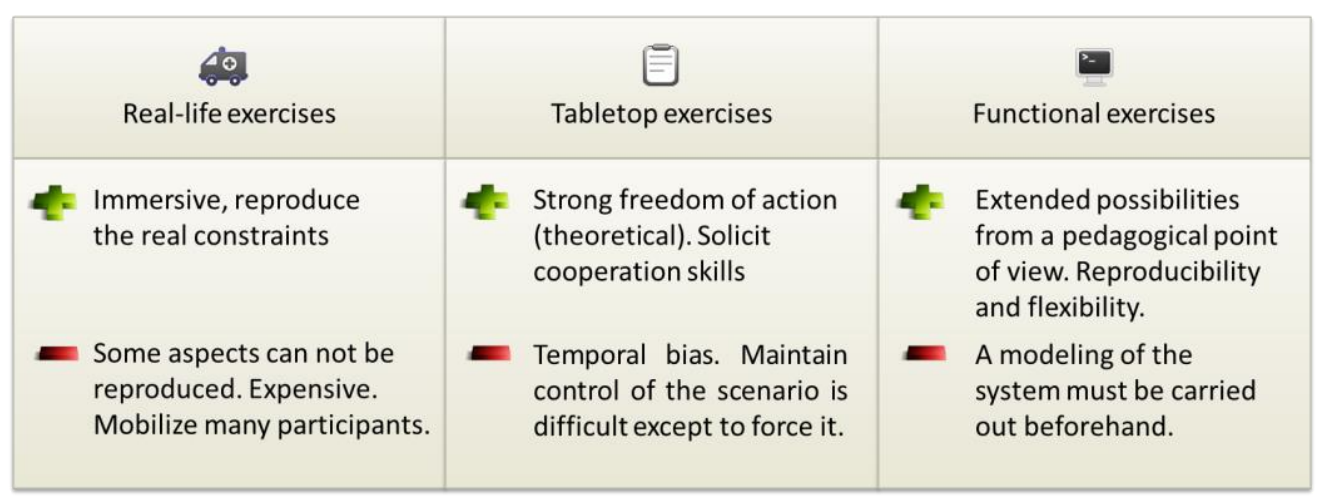

Fig. 2: pros and cons of the three main types of exercise

Then we have identified the following combination in order to reinforce the importance of the decision-making within a crisis cell: the use of functional exercises with an event-based approach and degraded conditions.

\subsection{Some examples of existing environments based on functional exercises}

The five following examples (the forest fire simulator of Valabre, the firefighter command training virtual environment, the multi-agent simulation for emergency response, the multi-agent simulation system of emergency response in disasters, and the iCrisis simulator) have been chosen because they are representative of the classical functionalities, limits and difficulties encountered in functional exercises.

\subsubsection{The forest fire simulator of Valabre}

The ECASC School of applied civil security (Valabre, France), has a simulation tool for firefighters and emergency managers (group leaders, tactical chiefs and heads of columns). A 3D environment is created by a virtual reality kernel contributing to immerse the users. As indicated in the tactical reasoning method used by the French firefighters, commands and controls are organized around collection and analysis of the situation, global reasoning, transmission of orders and receipt of situation reports. This method is achieved using real training aids, such as radios, telephones and the virtual use of airborne resources [Challot, 2002].

Although it does not cover all the skills needed in emergency management, this virtual environment allows the sharing of a common representation of the situation between all the stakeholders. Another advantage of this simulator is the use of realistic man-machine interfaces. However, we should note that the training is mainly based on the roles played by the instructors as the tool has limited management of the events. For example, the instructors partially control the scenario by manually adjusting the fire intensity. This approach may be realistic if the instructors are experts and are using the tool properly in order to steer the scenario in accordance with the 
initial teaching objectives. The main disadvantage is the need for a large number of instructors to guide the learners and manage all the events.

\subsubsection{Firefighter Command training Virtual Environment}

The GVU Center (Graphics, Visualization \& Usability, Atlanta, United States) has developed a training tool for the Fire Department of Atlanta [Julien and Shaw, 2003]. The three main modules of the simulator are:

- Simple virtual environment (SVE);

- Graphical user interface (GUI);

- Fire dynamics simulator (NIST Fire Dynamic Simulator).

The simulator is dedicated to tactical emergency managers, and each user controls a group of eight virtual firemen in order to fight building fires. An operator is responsible for interpreting the verbal commands of the users in order to update the system thanks to the GUI. This interface is a standalone application exchanging messages with the SVE. SVE then shows the 3D environment, the building fires (calculated according to Navier-Stokes equations) and the avatars (3D objects) [Julien and Shaw, 2003]. The crisis scenario changes as a function of the decisions that are taken by learners: decision trees are indeed used to navigate in the potential tipping points.

The main limit of this tool is due to the finite number of possible events. A scenario manager (an instructor) must collect the learners' decisions and convert them into events known by a predetermined database of implemented situations. We should therefore consider this virtual environment more as a demonstrator than a real simulator.

\subsubsection{Multi-agent simulation for emergency response}

The IRIT institute of computer science (Toulouse, France) has designed a tool in order to analyze the behaviors of stakeholders during a crisis [Bellamine et al., 2004]. Based on a multi-agent system (MAS), it aims to simulate the interactions between different actors at macroscopic level. Following the approach of modeling agents, the tool is mainly made up of an environment and a set of agents acting inside it. The different types of agents are victims or emergency stakeholders. The stakeholders can be emergency physicians or rescue workers. The former are able to make medical diagnoses and to provide first aid. The latter receive orders to evacuate the victims. The simulation is based on an initial state of the victims (between 0 and 4) and a probabilistic approach which enables to refresh this state over time (stabilization, deterioration, improvement).

We should note the use of MAS easily enables the configuration of a set of global parameters insofar as agents are a direct metaphor of reality. However, the retained approach is limited to 
emergency stakeholders decisions and ignores important elements such as dangerous phenomena or the other stakes involved in a real crisis (for example infrastructural and environmental stakes).

\subsubsection{Multi-agent simulation system of emergency response in disasters}

The simulator named MASTERD (University of Tokyo, Japan) has been developed to assess crisis management through the behaviors of the actors involved (national and local stakeholders, media, emergency services, etc.) [Kanno et al., 2006]. MASTERD is based on CORBA (Common Object Request Broker Architecture) and uses five modules:

- The "Simulation Kernel" (SK) manages the running of the tool (the clock cycles and the scheduling of the tasks) and the communication with the other modules. Thus, it ensures the flow of messages in the system thanks to a hierarchical structure based on FIPA-ACL (Foundation for Intelligent Physical Agents - Agent Communication Language) which differentiates three different performatives: information, request and order. The agents then activate automatic reactions according to the performatives received.

- The "Human-Organization Simulator" (HOS) is a module simulating the behavior of all elements involved by the crisis management. This includes a model of organization and a set of decision rules (Stimulus-Organization-Reaction model).

- The "Phenomena Simulator" (PS) provides information to other modules on the consequences of physical phenomena.

- The "Geographical Information System (GIS) server" contains geographical information such as the location of buildings and roads.

- The "Man-Machine Interfaces" (MMI) display simulation results and set up the initialization of the crisis scenario.

We can point out the architecture selected seems to make this tool easily extensible and reusable. Model changes also seem to be simple, by adding, removing or modifying each module independently. The agent decision-making is based on the notion of plans (a set of predefined actions). The developers indicate that the plans are stored in a specific base of knowledge built through an analysis of real emergency management [Kanno et al., 2006]. But it is important to note there is not much technical information available on the actual platform. So it is not possible to check whether this environment meets the needs of stakeholders.

\subsection{5 iCrisis}

This simulator is developed in part by the French ENSMN (Nancy, France) and aims to provide an organizational and a technological platform exploiting the Internet to perform simulations of virtual crises. The simulations are based on an observation methodology of decision-making 
processes in the groups of learners. The simulator involves five or six different cells: three or four crisis cells, one animation cell and one cell of journalists. The exercise stops when a supercritical step is reached and seems to be under control by the crisis cell [Verdel et al., 2010].

The skills monitored are mainly non-technical: ability to delegate, leadership, analytical synthesis, teamwork, communication, action in uncertainty and stress management. The cell of journalists creates a set of press articles and a video recording is performed during the training session in order to manage the debriefing.

We can note that iCrisis focuses on a particular aspect of the crisis management, including creative decision-making. Each exercise mainly covers one objective: to control a supercritical phase of the crisis identified beforehand. We should also note that between five to fifteen trainers are needed to oversee the groups of learners (the crisis cells and the media cell).

\subsection{Limits of existing environments}

First of all, it can be noted that most of the training environments for crisis management are intended for tactical or operational levels (emergency services, firemen, etc.), and not for strategic ones (stakeholders for example).

The study of other existing environments using functional exercises in crisis management has identified several limits. It is possible to distinguish those related to the unsuitability of the teaching strategy for the profile of learners, and those relating to the complexity of moderation for the trainers.

On the one hand, it is necessary to facilitate a proactive and participating immersion of the learners in a realistic environment and in a group as homogeneous as possible in terms of knowledge and experience. On the other hand, the role of the trainers is difficult as their authority may not be granted in a group of experts in crisis management. Nevertheless, they must promote success and explain the failures by factual reasons (particularly during the debriefing), while maintaining a certain distance from the learners. Some of these difficulties seem to be solved by the use of computer-assisted training [Kebritchi and Hirumi, 2008].

So we chose to open up the following three domains of improvements:

- The teaching strategy, in order to help trainers to create educational scenarios, to observe learners and to prepare the debriefing phase;

- The simulation system, which must help to make real-time, slow-time or fast-time simulations in order to simplify or highlight the studied phenomena, and to immerse the learners in a credible scenario; 
- The training environment, with the aim of deploying immersion devices and simulation kernels.

\section{HOW TO IMPROVE THE TEACHING STRATEGY?}

Four main areas are traditionally identified in the learning process [Houssaye, 2000]:

- Knowledge, necessary to make informed decisions;

- Know-how (savoir-faire), usually based on the acquisition of automatic reflexes;

- Being (savoir-être), by mobilizing factors of motivation, engagement, confidence and satisfaction in order to foster a favorable context for the performance;

- And social skills, usually studied through specific skills such as self-control and cooperation with the rest of the group.

The processes of teaching, learning and training associated with the previous components can be modeled by an educational tetrahedron as shown in Fig. 3 [Houssaye, 2000; Faerber, 2003]. This defines in a conceptual system the relations between the four entities involved: the learner, the teacher, the knowledge, and the group dynamics.

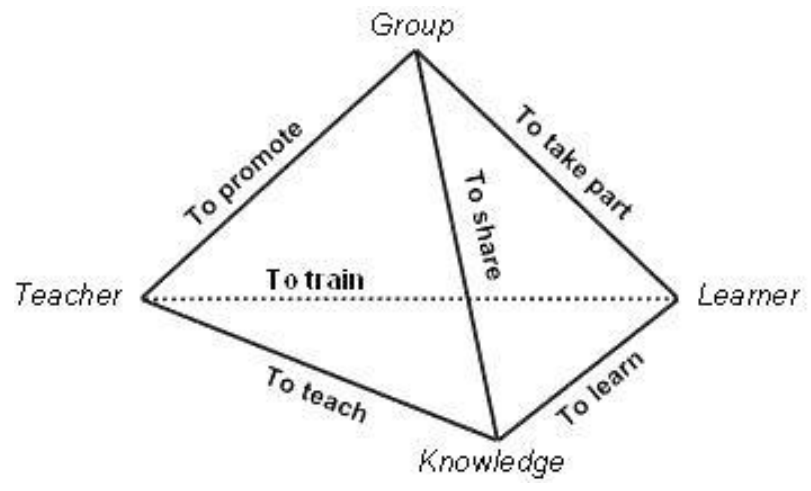

Fig. 3: educational tetrahedron of cooperative learning [Faerber, 2003].

Learning processes are part of the cycle "perception-data-information-knowledge-wisdom-vision" ensuring that decision-making does not affect the environment in which the group is situated [Le Bas, 1993; Carpenter and Hafner, 2008]. The sequence of these steps entails two prerequisites. The first is that any educational event must be perceptible in order to be picked up by the learner. The second highlights the need to integrate the heterogeneity of the learner profiles in the same group. The four classical approaches: behaviorism, cognitivism, constructivism and social constructivism differ in this respect [De Vries and Baillé, 2006].

Social constructivism deals better with the problems of collective learning, but it is found that it does not focus on the definition of a pedagogical framework suited to the learner profiles [Morin et al., 2004; Guéraud, 2005; Mucchielli, 2008]. We therefore propose to extend the social 
constructivist approach by a continuum of organizational learning that is structured around three steps, depending on whether the group is neophyte, intermediate or expert in crisis management. We will call these three steps the "beginner mode", the "intermediate mode" and the "expert mode". Our approach, in line with Pasin and Giroux, highlights the need to develop specific educational objectives and different assessment levels of the learners [Pasin and Giroux, 2010]. It is finally noted that the learning speed may be higher during the first two modes [Tena-Chollet, 2012]. An uninitiated audience increases its skills faster than a group of experts. Although our initial topic of research comes from the need of stakeholders (i.e. experts in crisis management) to be trained, we chose to retain also the two other learner profiles (neophyte and intermediate people), which are of considerable teaching interest.

\section{HOW TO IMPROVE THE SIMULATION SYSTEM?}

Business intelligence (BI) facilitates the anticipation and understanding of a situation, and decision-making. Interactive environments have several advantages: motivating the user, they help him/her to better understand complex or dangerous situations studying them with a different scale of view [Joab et al., 2006; Mendonça et al., 2006; Crichton, 2009].

The study of the typology of interactive environments for human learning distinguishes simulation games, microworlds and role playing games. Simulation games are considered suitable for training decision-makers because they integrate models, scenarios, unexpected events, timed processes, roles, procedures, decisions, consequences, indicators, symbols and helpful hardware [Crichton, 2009]. This type of serious game may consists of simulators for educational purposes, for the acquisition of technical and non-technical skills, of automatic reflexes, and of ways of thinking [Connolly et al., 2012]. These are used for demonstration purposes, self-training, self-assessment, or collaborative work. In every case, it relates a way of learning through discovery and action [Joab et al., 2006; Labat et al., 2006].

There are three modes which determine what the dominance of the simulation will be [Crampes and Saussac, 1999]: the position of independence, the position of competition and the position of cooperation. We should note that the third one has the advantage that the learners work together in order to develop their ability to achieve consensual decision-making. It is possible to make realtime, slow-time or fast-time simulations in order to simplify or highlight the studied phenomena but these settings must be justified from a pedagogical point of view [Joab et al., 2006]. The propensity of people to attach great importance to the visual aspect should encourage developers to allow the use of maps, data, and $2 \mathrm{D}$ or $3 \mathrm{D}$ representations in order to assess the impact of the crisis cell planning during the exercise [Morin et al., 2004]. 


\section{HOW TO IMPROVE THE VIRTUAL TRAINING ENVIRONMENT?}

Typically, virtual environments are destined for either technological or educational uses [Mellet d'Huart, 2001; Burkhardt, 2003]. In a pedagogical perspective, they are used to generate didactic interactions, and as a way of exercise management [Burkhardt, 2003]. In practice, stress of a crisis management can be recreated and so this can lead the learners to carry out tasks under conditions close to reality [Lourdeaux, 2001]. This approach improves the following types of learning: being, knowledge, know-how and social skills.

These objectives can be better achieved through multimedia interfaces, time constraints, information overload (Critical Thinking Training), and visual representations [Sniezek et al., 2001; Kebritchi and Hirumi, 2008]. The use of real data in interaction with a geographical information system is also a good way to ensure the realism of simulations. Several techniques already exist in order to facilitate integrations into various environments. Nevertheless, the use of virtual representations to produce new information asks the question of its consequences in an environment which aims to reproduce the real conditions of a crisis management. For Querrec, virtual representations are defined by three elements: immersion, imagination, and interaction [Querrec, 2002]. We should note that all three theoretically fit the immersive dimension needed in a crisis simulator, the participating and proactive behaviors expected from the learners in a serious game.

Two methods of representation are distinguished: virtual reality and virtual simulation [Pernin, 1996]. A comparison of these two methods highlighted that virtual simulation is more suited in our approach [Tena-Chollet, 2012]. Like virtual reality, the use of virtual simulations also allows to replay educational sequences, record data of the exercise, or make a break. However, virtual simulations allow greater reversibility actions [Burkhardt, 2003] thus giving the environment a strong didactic aspect. By any user involvement, the virtual simulation allows to repeat a scenario as many times as necessary, to intervene on the kinetics of the event, the occurrence of particular events, adding constraints, resources or concerning the evolution of the scenario. So, the disconnection from existing reality (implied with virtual reality) allows the learner decisions to be taken into account better, using temporal distortions if necessary, and replaying all the sequences to give the opportunity of retroactive corrections in case of bad choices.

The main disadvantage of the virtual simulation comes from the need to be constantly fed with calculated data, simulation models, computational behaviors, and more particularly a dynamic generation of crisis scenarios. Flexibility is usually viewed as an important factor in learning environments [Sun et al., 2006]. We propose using intelligent agents as the modeling paradigm for the crisis simulation, as in MASTERD. The design of a Multi-Agent System (MAS) requires the 
definition of the global system, expected behaviors of the agents, and the agents themselves [Sibertin-Blanc, 2001; Schurr et al., 2006]. Most particularly, the BDI software model (BeliefDesire-Intention) seems to constitute an initial basis in order to simulate human behaviors and accident phenomena [Wooldridge, 2002].

\section{SPECIFICATION OF A SEMI-VIRTUAL ENVIRONMENT FOR TRAINING}

The specification of an optimized training environment follows directly from our previous observations. We suggest two main sets of improvements: the first provides recommendations about the needed teaching-and-training strategy, while the second expresses practical tips in order to design a semi-virtual training environment for strategic crisis management. Finally, we propose a model in order to help people who want to design such a training environment.

\subsection{Teaching and training strategy}

The expected reactions of the learners seem to be spelled out before the training exercise. In practice, this requires a prior definition of the main, the intermediate and the specific learning objectives which will determine the needed events. With EBAT, two or three events must be created for each learning objective. These can vary in terms of difficulty at any time and the assessment of reactions can be made during the training exercise: an observer lists the performances of the learners according to the events they are facing. The debriefing step is then conducted on the basis of the observed behaviors.

We propose that the learning strategy and the content of each exercise depend on the profiles of the learners. For example, a raw novice must learn to identify viable strategies based on the crisis phases while an expert, by way of contrast, needs to work on interpersonal relationships within the crisis cell. Three teaching strategies will be established taking into account the type of learner (neophyte, intermediate or expert), associated with various objectives and then assessed differently.

Stress, resources and time management are the three main constraints that can hinder the process of decision-making. Assuming that a crisis imputable to human causes is more difficult to manage due to emotional involvement, the determination of a scenario should therefore both integrate the identified learning objectives and contribute to a motivating context for the crisis cell. More accurately, the instinct of cooperation within a group is activated and strengthened when problems or common difficulties are clearly seen and if there is at least one solution identified by a significant number of members of this group. So we propose that no event should be induced that 
cannot be associated with a possible solution. We also note that the cohesion of a training crisis cell must be maintained by a set of events (either recurrent or triggered on demand).

At the same time, the learners do not need to know each other or to have previously cooperated in order to be placed in a learning situation. However, automatic reflexes are only learned and reproduced if the context is the same as that for which the exercise is being conducted. It is important to reproduce the environment in which a learner will be during a real crisis. Four positive factors must be taken into account (instinct, learning, intelligence, adaptability) and six psychosocial weaknesses identified (alterability, subjectivity, ignorance, credulity, disaffection or asociality). We propose to consider these ten elements as "degrees of training" (DOT) in order to define each crisis scenario and lead to an instructive debriefing.

So, we consider that general, intermediate and specific skills must be specified. We propose six general skills: anticipation (1), communication (2), cooperation (3), stress management (4), decision-making (5), and strategic steering (6). These skills are used to achieve five intermediate sets of tasks: management of the crisis consequences (1), tactical and operational response (2), crisis cell management (3), crisis communication (4), and overall view in the short, medium, and long term (5). In addition, we have identified sixteen groups of "expected actions": human management (1), resource management (2), hazard assessment (3), identification of issues involved (4), strategies for returning to normal state (5), protection of threatened high-stake elements (6), reinforcement management (7), analysis of the situation (8), management (9) and arbitration (10) of strategic options, four types of communication - within the crisis cell (11), with media (12), authorities (13), or the public (14), monitoring and forecasting (15), and identifying the possible scenario changes (16). These 16 last skills have to be improved through events and interactions induced by the crisis scenario.

Conventionally, the main phases of a training session are planning, preparation, the exercise itself, and debriefing. This last step is very important because it leads to the acquisition of knowledge by a reflexive analysis of the decision-making. The debriefing must follow specific rules. Indeed, the errors made by the learners should not lead to a value judgment. The aim of this step is to reveal the origin of these errors and to understand why they occurred (cognitive process of reconstruction). Therefore, we propose the following evaluation categories for all phases of the continuum of organizational learning: anticipation, communication, teamwork, stress management, decision-making, and leadership. These elements are thus identified as the main objectives which need to be specified. These objectives can be completed in real time by observers with checklists in order to identify how the group organises itself to deal with the crisis, the leadership involved, the sharing of information, coordination, the way decisions are taken. The 
checklists can give the results of the training room observations to inform facilitators about the trainees' reactions during the exercise.

When a situation begins with incomplete information, and moves forward in time, new information is known and may show that the initial decisions are no longer adequate. So, others methods can be investigated (trees of knowledge for example) in order to identify the profile of the group (from a teamwork point of view) and to focus on the recognition and the management of these potential errors.

Finally, the use of a semi-virtual environment does not exclude the intervention of one or more trainers. They are essential as they guide the learners to the predefined didactic situations. Roleplay guides should thus be created in order to help the trainers. Nevertheless, it is not recommended that the trainers should intervene during an exercise. The way learners will be led to the didactic situations must be defined, insofar as these aspects must be performed implicitly.

\subsection{Definition of a new kind of environment}

Using a training environment has many advantages. The first is to submit a global scenario to a group of learners (here, a training crisis cell). It is also possible to perform dynamic simulations of complex systems (like crisis scenarios) in order to understand them more easily than with static representations. These simulations leave more room for mistaken decision-making because all the events are virtual, and all the consequences are reversible. By contrast with full-scale exercises, it is possible to replay a pedagogical sequence, stop it and save it at any time. Moreover, we should point out the possibility to add some stress in this kind of environments. This is essential to be psychologically faithful to emergency situations. It is noteworthy that in comparison with other teaching methods, learning through this type of environment presents the advantage of generating motivation for learners [Shih et al., 2007], and three components are usually designed: the representation devices, the data input devices, and the virtual representation kernel [Burkhardt, 2003].

From our point of view, there is one type of representation naturally appropriate to strategic decision-making: virtual simulation. Unlike virtual reality, which is based on the use of realistic interfaces (objects, tools, utensils, etc.), virtual simulation is dedicated to the emulation of possibly fictitious situations whose perception and interpretation can differ between two learners. Particularly, we consider that the learners should improve their shared mental models during crisis scenarios. In addition, virtual simulation seems to offer the best compromise between the concept of interaction with the virtual environment, immersion in a crisis scenario, and the imagination needed on the part of the learners. It is reminded that any training environment must be mainly 
based on learning objectives. It is therefore possible intentionally to deviate from reality, if warranted from an educational point of view (as long as the events remain credible). The interaction can occur through many senses, notably vision. So the use of graphical knowledge elements is highly recommended, knowing full well that they do not need to be hyper-realistic.

We suggest on the one hand that a supervisor manages the crisis scenarios and moderates the decisions of the training crisis cell. On the other hand, trainers must be able to play roles of the actors involved by the crisis. Two main types of scenario can be embedded in a simulator:

- Canvas scenarios setting a number of rules before the beginning but then allowing free interactions to take place.

- Programmed-scenarios with a set of actions planned in advance; these actions can be optional or not.

We consider that canvas scenarios increase imagination and satisfy all the elements that need to be integrated in simulations while enabling the integration of experience feedback. In order to dynamically simulate a real or fictitious crisis scenario, the multi-agent approach seems to be appropriated, particularly to model canvas-rules (e.g. physical effects or human behaviors), and then to let the system self-organize and schedule all the crisis events. The study of the main MAS indicates the BDI approach, which is based on Stimulus-Organization-Reaction models, as a coherent work perspective in order to simulate agents' behaviors during a virtual crisis.

\subsection{New model proposed}

We propose a methodology of design based on 7 steps (Fig. 4) in order to model a semi-virtual training environment for crisis management: the specification of the environment, the specification of the users, the kernel design, the scenario modelling, the educational simulation, the assessment of the learners, the man machine interfaces, and the assessment of the learners (required for the debriefing step).

Step 1 concerns the specification of the environment and integrates the training chronology, the structuration of the subsystems involved and the expected features (what are the immersion devices and software involved?, how many people to train?...). Finally, a physical infrastructure and information technology architecture can be defined.

Step 2 includes the specification of the users (learners and trainers) and the modalities of interactions (phones?, emails?, fax?...).

Step 3 concerns the kernel design (the multi-agent system) and includes hazards (in the form of a hierarchy of phenomena), high-stake elements (typology of possible human, material and environmental issues), and tactical and operational actors that have to be also simulated. 
Step 4 and step 5 concern the creation and the simulation of a crisis scenario. These steps integrate the educational objectives and imply the specification of activation rules for the events of the scenario.

Step 6 involves the design of man machine interfaces in order to help trainers to moderate the exercises.

Finally, step 7 assembles all the techniques and tools required for debriefing.

Step 1:

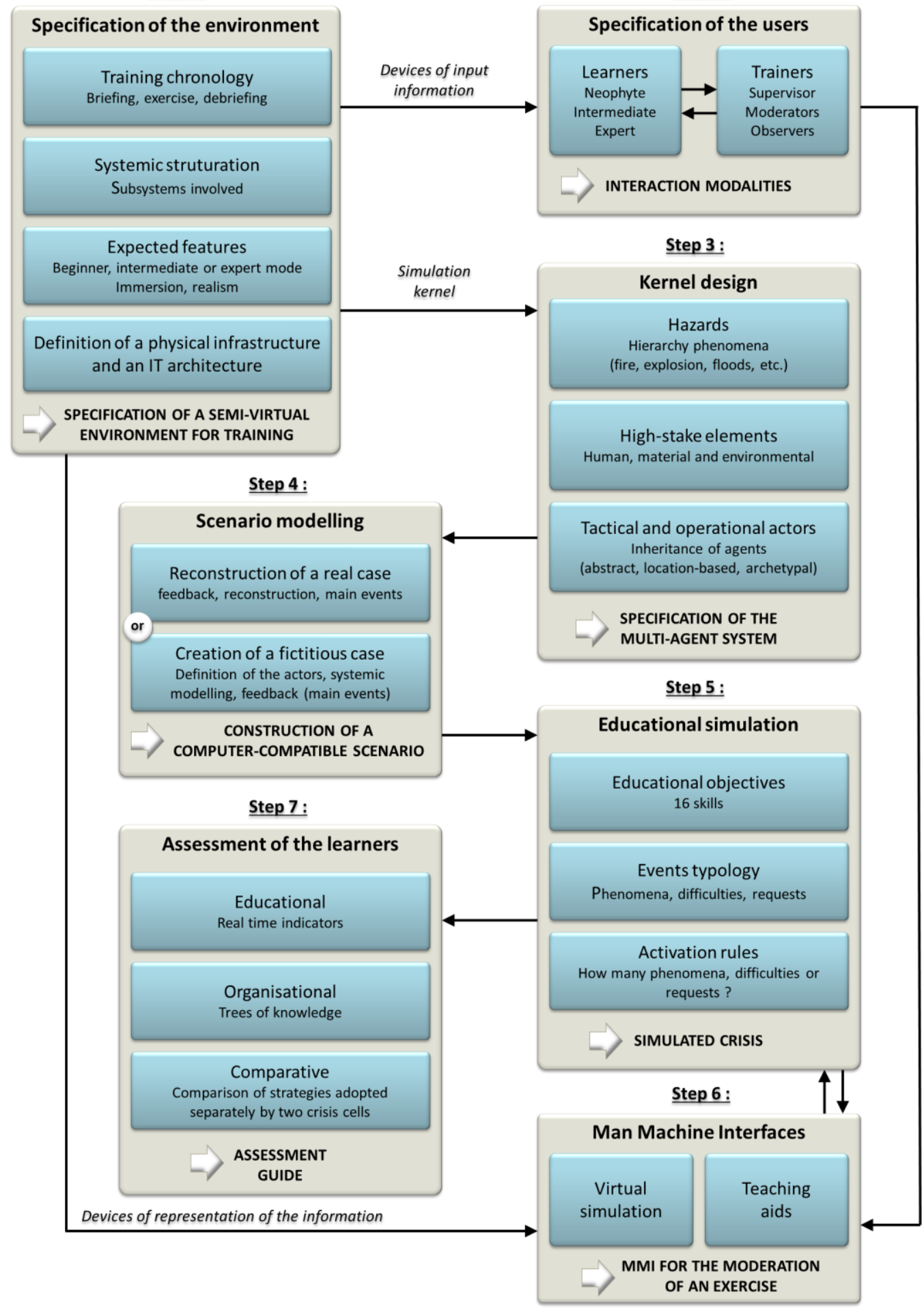

Fig. 4: model proposed for the design of a semi-virtual training environment for crisis management. 


\section{CONCLUSION}

Emergency situations confront organizations with critical problems, stakeholders with stress and the obligation to minimize the potential consequences on high-stake elements. In a crisis cell, decision-makers have to mobilize various technical and non-technical skills through teamwork. However, we have highlighted that the need for experience implies regular training of the stakeholders involved. The state-of-the-art study situated our research at the confluence of the pedagogical and technological difficulties typically encountered.

Simulation games have mostly been characterized as a form of experiential learning, because the process of knowledge creation relies on the transformation of self-experience. We have identified a social constructivist learning continuum which integrates three steps from a "beginner mode" through an "intermediate mode" to an "expert mode". The use of functional training exercises may reinforce the importance of the decision-making within a closed group. The basis of this eventbased approach to training is the simulation of events that can occur in order to make learners aware of the key concepts put at stake. During a virtual exercise, the learners must be faced with dilemmas requiring naturalistic decision-making, and thus be able more easily to share existing or new mental models. We also recommend that the emergency dimension can be integrated using a critical-thinking training approach to raise the learners' awareness of optimizing the ratio of reaction time versus the amount of available information. A typology of educational objectives was identified, with six general skills, five intermediate sets of tasks, and sixteen groups of expected actions. All these expected forms of behavior fit our concept of DOTs (Degrees Of Training), and must be stimulated by events in a crisis scenario.

In this paper we propose a new approach to emergency management training and suggest a set of specifications in order to design a semi-virtual environment. Our study shows that simulationbased serious games need to define models, scenarios, unexpected events, timed processes, role guides, procedures, decisions, consequences, indicators, symbols and a specific infrastructure. From educational and technical points of view, canvas-scenarios linked with virtual simulations seem to be a good way to simulate and represent a real or a fictitious situation. This approach entails a simulation kernel for which we suggest a multi-agent system. The relations between the agents may follow a belief-desire-intention software model and the behaviors may implement a stimulus-organization-reaction approach. Finally, a specific debriefing methodology is needed for the assessment of the learners in order to take into account the ten DOT (degrees of training) chosen, and thus the performances, different profiles and skills used during each exercise. These 
recommendations will be applied in our semi-virtual training environment for crisis management, and further analyzed and commented.

\section{REFERENCES}

Bates E., Thal D., Marchman V. (1991), "Symbol and syntax: a darwinian approach to language development", in Krasnegor N.A., Rumbaugh D.M., Schiefelbusch R.L., Studdert-Kennedy M., (Ed), "Biological and behavioral determinant of language development", Lawrence Erlbaum Associates, Hillsdale.

Bellamine N., Saoud B., Darcy S., Dugdale J., Pavard B., Ben Ahmed M. (2004), "Simulation multi-agents de situation de secours d'urgence", Informatique et Santé, 2004 (16) : 15-16.

Blickensderfer E., Cannon-Bowers J.A., Salas E. (1998), “Cross-Training and team performance.”, In Cannon-Bowers J., Salas E. (Eds), "Making decision under stress. Implications for individual and team training”, Washington, DC: American Psychological Association, pp. 299-311.

Bryant D.J., Webb R.D.G, McCann C. (2003), "Synthétiser deux modes d'approche de la prise de décision pour le commandement et le contrôle", Revue militaire canadienne, pp.29-34., 2003.

Burkhardt J. M. (2003),” Réalité virtuelle et ergonomie : quelques apports réciproques”, Le travail humain 66(1):6591.

Buser P., "La conscience animale", Pour la science, 302:84-87, 2002.

Cannon-Bowers J.A., Salas E., Converse S. (1993), "Shared mental models in expert team decision making", in Castellan N., (Ed.), “Individual and Group Decision Making: Current Issues, Hillsdale”, NJ: Erlbaum, 1993.

Carpenter S. A., Hafner W. (2008), "The Vision Hierarchy of Understanding: Explanation and Evidence for the Emergence of Data, Information, Knowledge, and Wisdom", Graduate School of Computer and Information Sciences, NSU.

Challot A. (2002), "Le pôle vert de Valabre. Les institutions pour la protection de l'environnement présentes sur le site de Valabre et leur function”, Forêt méditerranéenne, ISSN 0245-484X, T. XXIII, n², 2002, pp. 149-158.

Cohen M.S., Freeman J.T., Thompson B. (1998), "Critical thinking skills in tactical decision making: a model and a training strategy", In Cannon-Bowers J., Salas E. (Eds), "Making decision under stress, Implications for individual and team training", Washington, DC: American Psychological Association, pp. 155-190.

Connolly T.M., Boyle E.A., MacArthur E., Hainey T., Boyle J.M. (2012), “A systematic literature review of empirical evidence on computer games and serious games", Journal of Computer \& Education.

Crampes M., Saussac G. (1999), "Facteurs de qualité et composantes de scénario pour la conception de simulateurs pédagogiques à vocation comportementale". Sciences et techniques éducatives, vol. 6, num. 1, pp. 11-36.

Crichton M. T. (2009), "Improving team effectiveness using tactical decision games", Safety Science 47(3): 330, 0925-7535.

Crocq L., Huberson S., Vraie B. (2009), "Gérer les grandes crises sanitaires, écologiques, politiques et économiques", Odile Jacob, 2009.

Dautun C. (2007), "Contribution à l'étude des crises de grande ampleur: connaissance et aide à la décision pour la Sécurité Civile”, Doctoral Thesis, Ecole Nationale Supérieure des Mines de Saint-Etienne, 2007. 
De Vries E., Baillé J. (2006), “Apprentissage : référents théoriques pour les EIAH”, Lavoisier (Ed.), Environnements informatiques pour l'apprentissage humain, Hermes-science: 384.

Denis H. (1993), “Gérer les catastrophes, l'incertitude à apprivoiser”, Les Presses Universitaires de Montréal, Montréal, 248p., 1993.

Endsley M. (2003), “Designing for situation awareness in complex systems”, Conférence sur les facteurs humains de prise de décision dans les systèmes complexes, Dunblane, Ecosse, 2003.

Faerber R. (2003), “Groupements, processus pédagogiques et quelques contraintes liés à un environnement virtuel d'apprentissage", EIAH (Environnements Informatiques pour l'Apprentissage Humain), Strasbourg, 2003.

Fowlkes J.E., Dwyer D.J., Oser R.L., Salas E. (1998), “Event-based approach to training.”, The International Journal of Aviation Psychology, numéro 8, pp. 209-221, 1998.

Galvão J.R., Martins P.G., Gomes M.R. (2000), "Modeling Reality with Simulation Games for a Cooperative Learning”, The 2000 Winter Simulation Conference, Orlando, USA, pp. 1692-1698, 10-13 Décembre 2000.

Guéraud V. (2005), “Approche Auteur pour les Situations Actives d’Apprentissage: Scénarios, Suivi et Ingénierie”, Habilitation à Diriger des Recherches, Université Joseph Fourier - Grenoble 1, Grenoble, Informatique.

Heiderich D. (2010), "Plan de gestion de crise : organiser, gérer et communiqué en situation de crise", Dunod, 2010.

Houssaye J. (2000), “Théorie et pratiques de l'éducation scolaire: le triangle pédagogique”, Peter Lang, 2000.

Joab M., Guéraud V., Auzende O. (2006), "Les simulations pour la formation”, Environnements informatiques et apprentissages humains, éditeurs M. GrandBastien, J-M Labat, Traité IC2, Hermès, 2006.

Julien T. U. S., Shaw C. D. (2003), "Firefighter Command Training Virtual Environment", In Richard Tapia Celebration of Diversity In Computing, Proceedings of the 2003 conference on Diversity in computing, pages 30 - 33, Atlanta, Georgia, USA: ACM.

Kanno T., Morimoto Y., Furuta K. (2006), “A distributed multi-agent simulation system for the assessment of disaster management system”, International Journal of Risk Assessment and Management, 6, 4-6, 528.

Kebritchi M., Hirumi A.C. (2008), "Examining the pedagogical foundations of modern educational computer games", Computers \& Education 51(4): 1729.

Klein G. (1997), “The recognition-primed decision (RPD) model: looking back, looking forward.”, In Zsambok C., Klein G., "Naturalistic Decision Making”, 1997, Mahwah, NJ: Erlbaum.

Labat J.M., Pernin J.P., Guéraud V. (2006), “Contrôle de l'activité de l'apprenant: suivi, guidage pédagogique et scénarios d'apprentissage", Hermès, Paris. Environnements Informatiques et Apprentissage Humain, Hermès-Lavoisier, pp.201-222, 2006, Collection IC2.

Lachtar D., Garbolino E. (2012), "Performance Evaluation of Organizationnal Crisis Cell : methodological proposal at communal level”. Christophe Berenguer, Antoine Grall, Carlos Guedes Soares, Editors. European Safety and Reliability Conference: Advances in Safety, Reliability and Risk Management, ESREL 2011, Sep 2011, Troyes, France. CRC Press, pp.165-172 - ISBN: 9780415683791, 2012.

Laffitte J., Howe R.M. (1997), "Interfacing fast and slow subsystems in the real-time simulation of dynamic systems", Transactions of the Society for Computer Simulation Volume 14, Issue 3, ISSN: 07406797, CODEN: TSCSE.

Lagadec P. (1995), “Cellule de crise, les conditions d'une conduite efficace”, Les éditions d'organisation, Paris, 1995.

Lagadec P. (2001), "Les exercices de crise: pour des ruptures créatrices”, Institut Européen de Cindyniques, Lettre ${ }^{\circ}$ 34 - juillet août 2001.

Lagadec P. (2007), “Enseigner la question des crises : Enjeux, Obstacles, Initiatives.”, Cahier du Laboratoire d'Econométrie, numéro 2007-01, Ecole Polytechnique, Paris, Janvier 2007. 
Le Bas C. (1993), "La firme et la nature de l'apprentissage”, Economies et Sociétés, Série Dynamique technologique et organisation(1): 7-24, 1993.

Loosemore M. (1998), “Organisational behaviour during a construction crisis”, International Journal or Project Management, Vol. 16, N², pp. 115-121.

Lourdeaux D. (2001), "Réalité Virtuelle et Formation: Conception d'Environnements Virtuels Pédagogiques", Thèse de Doctorat, Ecole des Mines de Paris, Paris, Informatique Temps Réel, Robotique et Automatique.

Marguin J. (2002), “Approche systémique des crises et aide à la décision stratégique”, L’Armement.

Mawdesley M., Long G., Al-jibouri S., Scott D. (2011), “The enhancement of simulation based learning exercises through formalised reflection, focus groups and group presentation”, Computers \& Education, 56(1), 44-52. doi:10.1016/j.compedu.2010.05.005.

Means B., Salas E., Crandall B., Jacobs T.O. (1993), “Training decision makers for the real world”, In Klein G.A., Orasanu J., Calderwood R., Zsambok C.E., "Decision Making in Action: Models and Methods”, Norwood, NJ: Ablex Publishing Corp., pp. 306-326.

Mellet d'Huart D. (2001), "La réalité virtuelle: un média pour apprendre”, Cinquième Coloque Hypermédias et Apprentissage, Grenoble, France.

Mendonça D., Beroggi Giampiero E.G., Van Gent Daan, Wallace William A., (2006), "Designing gaming simulations for the assessment of group decision support systems in emergency response", Safety Science, Volume 44, Issue 6, July 2006, Pages 523-535, ISSN 0925-7535, http://dx.doi.org/10.1016/j.ssci.2005.12.006.

Morin M., Jenvald J., Thorstensson M. (2004), "Training first responders for public safety using modeling, simulation, and visualization”, SIMSafe, Karlskoga, Suède, 15-17 June, 2004.

Mucchielli R. (2008), “Les méthodes actives dans la pédagogie des adultes”, ESF éditeur, Paris, ISBN 978-2-7101$1979-1$.

Parkin J. (1996), “Organizational decision making and the project manager", International Journal of Project Management, Vol.14, N5, pp257-263.

Pasin F., Giroux H. (2010), “The impact of a simulation game on operations management education”, Journal of Computers \& Education.

Pearson C.M., Kovoor-Misra S., Clair J.A., Mitroff I.I. (1997), "Managing the Unthinkable”, Organizational Dynamics, Autumn, pp. 51-64.

Pernin J.-P (1996), “M.A.R.S. Un modèle opérationnel de conception de simulations pédagogiques", Thèse de doctorat, Université Joseph Fourier - Grenoble I, Grenoble.

Querrec R. (2002), “Les systèmes multi-agents pour les environnements virtuels de formation”, Thèse de doctorat, Université de Bretagne Occidentale.

Rasmussen J. (1983), "Skills, rules, and knowledge; signals, signs, and symbols, and other distinctions in human performance models," Systems, Man and Cybernetics, IEEE Transactions on , vol.SMC-13, no.3, pp.257,266, May-June 1983, doi: 10.1109/TSMC.1983.6313160.

Salas E., Cannon-Bowers J.A. (1997), “The anatomy of team training”, In Tobias L., Fletcher D., "Handbook on research in training", MacMillan, New York.

Sayegh L., Anthony W.P., Perrewé P.L. (2004), "Managerial decision-making under crisis: the role of emotion in an intuitive decision process", Human Resource management Review, Vol. 14, pp. 179-199.

Schaafstal A.M., Johnston J.H., Oser R.L. (2001), “Training teams for emergency management”, Computer in Human Behavior, volume 17, publication 5-6, pp. 615-626. 
Schurr N., Pratik P., Fred P., Milind T. (2006), "Using Multiagent Teams to Improve the Training of Incident Commanders", Fifth International Joint Conference on Autonomous Agents and Multi Agent Systems (AAMAS) Industry Track, 2006.

Shanteau J. (1987), "Psychological characteristics of expert decision makers", In Mumpower J.L., Renn O., Philipps L.D., Uppuluri V.R.R., “Expert Judgment and Expert Systems”, Berlin, Allemagne : Springer-Verlag, pp. 289-304.

Shih M., Feng J., Tsai C.-C. (2007), "Research and trends in the field of e-learning from 2001 to 2005: A content analysis of cognitive studies in selected journals".

Sibertin-Blanc C. (2001), “Concurrent object-oriented programming and petri nets table of contents”, Springer-Verlag New York, Inc. Secaucus, NJ, USA, 2001.

Smith W., Dowell J. (2000), “A case study of co-ordinative decision-making in disaster management”, Ergonomics, volume 43, numéro 8, pp. 1153-1166, 2000.

Sniezek J.A., Wilkins D.C, Wadlington P.L. (2001), “Advanced Training for Crisis Decision Making: Simulation, Critiquing, and Immersive Interfaces", Hawaii International Conference on Systems Sciences, Maui, Hawaï, 5-7 Janvier 2001.

Sun P.-C., Tsai R.J., Finger G., Chen Y.-Y., Yeh D. (2006), "What drives a successful e-Learning? An empirical investigation of the critical factors influencing learner satisfaction".

Tena-Chollet F. (2012), “Elaboration d'un environnement semi-virtuel de formation à la gestion stratégique de crise, basé sur la simulation multi-agents”, Doctoral Thesis, Ecole Nationale Supérieure des Mines de St-Etienne.

Tena-Chollet F., Tixier J., Mangin J-F., Dusserre G. (2013), "Development of a spatial risk assessment tool for the transportation of hydrocarbons: methodology and implementation in a Geographical Information System", Journal of Environmental Modelling \& Software, http://dx.doi.org/10.1016/j.envsoft.2013.02.010.

Trnka J., Jenvald J. (2006), "Role-Playing Exercise - A Real-Time Approach to Study Collaborative Command and Control”, International Journal of Intelligent Control and Systems, volume 11, numéro 4, pp. 218-228.

Turner B.A. (1978), “Man-Made Disaster”s, The Wykeham Science Series, Wykeham Publications, First edition, London, 254p, 1978.

Verdel T., Tardy A., Lopez P., Hansen C., Deschanels J.L., Abdel-Aziz S. (2010), "iCrisis" ${ }^{\mathrm{TM}}$ : un dispositif original de simulation de gestion de crise”, communication n¹62, Congrès Lambda-mu 17 (Innovation et Maîtrise des Risques), La Rochelle, 5-7 octobre 2010.

Weisæth L., Knudsen J., Tonnessen A. (2002), “Technological disasters, crisis management and leadership stress”, Journal of Hazardous Materials, numéro 93, pp. 33-45.

Wooldridge M. (2002), “An Introduction to MultiAgent Systems”, Second Edition, 2002.

Wybo J-L., Madland Kowalski K. (1998), “Commands centers and emergency management support”, Safety Science, volume 30, publication 1-2, pp. 131-138. 